\title{
UTJECAJ UČESTALOSTI PRISTUPANJA E-NASTAVNIM SADRŽAJIMA BIOLOGIJE NA USVOJENOST OBRAZOVNIH ISHODA
}

\author{
Daniela Novoselić ${ }^{1}$, Mila Bulić ${ }^{2}$ \\ ${ }^{1}$ ALFA d.d., Zagreb, Hrvatska \\ daniela.novoselic@alfa.hr \\ ${ }^{2}$ Filozofski fakultet, Split, Hrvatska
}

\begin{abstract}
SAŽETAK
Cilj rada bio je istražiti učestalost pristupanja nastavnim sadržajima biologije i usvojenost obrazovnih ishoda pomoću Moodle sustava, a kroz njegovu implementaciju u nastavi biologije osmog razreda osnovne škole u sklopu nastavne teme „Sastav tijela,, razmnožavanje i razvitak“. Istraživanje je provedeno s učenicima koji još nisu imali iskustvo e-učenja, u dobi 14 godina. Temeljem cilja istraživanja postavljena je hipoteza: ako učenici tijekom pet tjedana učenja pristupaju učestalo nastavnim sadržajima iz biologije u sustavu e Moodle, ostvarit će bolji rezultat na pisanoj provjeri znanja. Kako bi se dobio uvid u očekivanja učenika o učinkovitosti prihvaćanja učenja biologije primjenom sustava Moodle provedena su dva upitnika s pitanjima na koja su odgovori bili mogući unutar 5-stupanjske skale Likertovog tipa. Prvi upitnik koji su učenici rješavali prije početka e-učenja imao je za cilj dobiti informaciju o tome što učenici očekuju od e-učenja, kakvu predodžbu imaju o eučenju, kakva su njihova očekivanja o takvom načinu poučavanja i učenja. Drugi upitnik rješavali su nakon završetka e-učenja, u svrhu provjere učeničkih iskustava o učinkovitosti i zadovoljstvu učenja nastavnih sadržaja pomoću Moodle sustava. E-učenje ispunilo je očekivanja učenika vezana uz jasnoću i zanimljivost teksta elekcija i pripadnih pitanja, preglednost glavnog izbornika, zastupljenost slika i filmova. Analiza rezultata učestalosti pristupanja nastavnim sadržajima pokazala je da su učenici koji su češće pristupali nastavnim sadržajima ostvarili bolji rezultat na pisanoj provjeri znanja. Izostalo je aktivno učeničko pristupanje nastavnim sadržajima u sustavu Moodle u razdobljima kada se nije odvijala nastava u učionici informatike.
\end{abstract}

Ključne riječi: e-učenje, Moodle, očekivanja učenika, nastava biologije, nastavna teme "Sastav tijela, razmnožavanje i razvitak", 8. razred

\section{UVOD}

E-učenje najčešće se definira kao skup aplikacija i procesa (Astd, 2001), kao što je učenje temeljeno na Web-u (eng. Web-based learning), učenje temeljeno na računalu (eng. computer-based learning), virtualni razredi (eng. virtual classrooms) i digitalna suradnja (eng. digital collaboration), koji omogućavaju pristup nastavnim sadržajima pomoću različitih elektroničkih medija (CD-ROM, Internet, intranet, extranet, audio i video, satelit itd.). E-učenje u središte stavlja učenika za razliku od tradicionalne nastave $u$ razredu koja u središte stavlja učitelja i njegovu kontrolu nad razredom, nastavnim sadržajem i procesom poučavanja i učenja. Sustavi e-učenja omogućavaju interaktivno učenje vlastitim ritmom, u jednostavnom, fleksibilnom, distribuiranom okruženju za učenje (Khan, 2001).

Današnji aktualni pristup e-učenju vezan je uz pojavu WEB 2.0 (Social Web) i 3D tehnologije, gdje je u fokusu medijsko-didaktičkog interesa oblikovanje digitalnih okolina učenja u kojima će i informalno učenje biti u funkciji postizanja boljeg uspjeha u učenju (Rodek 2010). Nova web tehnologija donosi nove mogućnosti za suradnju, razmjenu, blogove i virtualnu socijalnu mrežu.

Moodle je aplikacija za izradu i održavanje online kolegija putem Interneta. Ovaj sustav za upravljanje učenjem pruža nastavnicima punu računalnu podršku pri organizaciji i izvođenju online nastave: mogu uređivati sadržaje nastavne teme, dodavati nove nastavne sadržaje, ocjenjivati učeničke radove, pregledavati i statistički obraditi podatke o učeničkim postignućima. Učenici mogu sadržaje 
pregledavati, rješavati provjere znanja, koristiti alate za komunikaciju i kolaboraciju (zajednički rad). Moodle omogućuje učenicima ostvarivanje participacije, suradnje, komentiranja, socijalne konstrukcije znanja te veliki stupanj autonomije u procesu učenja (Grubišić, 2007).

Nastava iz predmeta biologije i srodnih prirodoslovnih predmeta najčešće se provodi na tri načina: u učionici, u praktikumu/specijaliziranoj učionici te u prirodi (Orion i sur., 1997). U posljednjih desetak godina, unatoč intenzivnom razvoju informatičkih sustava $i$ njihove svekolike prisutnosti $u$ svakodnevnom životu, čini se da se nisu bitno promijenili načini poučavanja nastave prirodoslovnih predmeta, u ovom slučaju biologije (De Corte, 2000). To je začuđujuće budući da je učenicima na svim razinama obrazovanja Internet postao primarni izvor informacija kako za osobne potrebe, tako $\mathrm{i}$ za školske potrebe. Rowlands i sur. (2008) u svom radu nazivaju ih "Google generacija učenika". Primarno današnji učenici Internet koriste gotovo za sve: od zabave, igrica, komunikacije/kolaboracije putem socijalnih mreža, za dijeljenje ili komentiranje nekog sadržaja, do potrage za nekom informacijom, izradom nekog projekta, prezentacije. Upravo stoga se osjeća nužnost implementacije, učenicima tako bliske digitalne tehnologije i Interneta, u nastavu prirodoslovnih predmeta.

Pod pojmom prirodoslovne pismenosti podrazumijeva se sposobnost korištenja prirodoslovnog znanja, prepoznavanje pitanja i izvođenje zaključaka temeljenim na dokazima u cilju razumijevanja i lakšeg donošenja odluka o prirodnom svijetu i promjenama koje u njemu izaziva ljudska aktivnost (Braš - Roth, 2008). Hrvatski Nacionalni okvirni kurikulum (MZOŠ, 2011) definira prirodoslovno područje kao cjelinu koja se temelji na spoznajama slijedećih prirodnih znanosti: biologije, kemije, fizike, geografije i geologije. Temelji biološke prirodoslovne kompetencije počinju se oblikovati u programima predmeta „Priroda i društvo“ u prva četiri razreda osnovne škole, a nastavljaju se u sadržajima predmeta "Priroda“ u petom i šestom razredu te u predmetu „Biologija“ u sedmom i osmom razredu osnovne škole. Školskom je učenju biologije cilj poticati i upotpuniti spoznaje o značajkama, strukturama, funkciji, raznolikosti, rasprostranjenosti, međusobnoj povezanosti i promjenjivosti živog svijeta, razvijati pozitivne stavove prema prirodi te spoznati vlastitu biologiju.

Programska koncepcija po kojoj se uče biološki sadržaji u osnovnoj školi gotovo je u nepromijenjenom obliku od šezdesetih godina prošlog stoljeća (Zavod za školstvo Ministarstva kulture i prosvjete Republike Hrvatske, 1993; Garašić, 2012). Uvođenje HNOS-a 2006. godine (MZOŠ, 2006) sadržajno nije donio promjene u nastavnom programu. Programska koncepcija nastave biologije u hrvatskom školstvu ne prati razvoj biološke znanosti i nije prilagođena stupnju kognitivnog razvoja učenika. Veza između razvoja biologije kao znanosti i škole očituje se nažalost samo u porastu broja termina i činjenica koje učenici moraju usvojiti (Wood, 2009; Dikmenli, 2010). U svojim su istraživanjima brojni autori (Glasser, 1994; Ramsden, 1998; Garašić, 2012) ukazali na trend opadanje učeničkog interesa za učenje prirodoslovlja. Iz svega proizlazi potreba iznalaženja novih strategija poučavanja koje će djelovati na povećanje interesa i motivaciju učenika za usvajanjem obrazovnih ishoda iz prirodoslovnih predmeta. Implementacija e-učenja u nastavni proces samo je jedna od mogućnosti kojima se želi doprinijeti boljem usvajanju koncepata u nastavi biologije.

Nastavni program biologije u osmom razredu obuhvaća biologiju čovjeka. Obrađuju se organski sustavi, a unutar svakog sustava uči se povezanost građe i funkcije, o poremećajima i bolestima te o zaštiti, uz naglasak na zdravstvenom prosvjećivanju i odgoju. Nastavna tema „Sastav tijela, razmnožavanje i razvitak“ upoznaje učenike s građom spolnih organa, razmnožavanjem te 
odgovornim spolnim ponašanjem. Ova se nastavna tema realizira kroz nastavne jedinice: 1 . Građa i uloga spolnih organa; 2 . Začeće i razvitak djeteta prije rođenja; 3 . Od rođenja do smrti; 4 . Odgovorno spolno ponašanje.

Rezultati istraživanja (Garašić, 2012) pokazali su slabu učeničku usvojenost obrazovnih ishoda ove nastavne teme. Tako su primjerice učenici pri analizi uspješnosti učenja pokazali slabu usvojenost obrazovnih ishoda o fiziološkim procesima i događajima tijekom menstruacijskog ciklusa kao i slabu riješenost zadataka koji se odnose na građu i ulogu muških i ženskih spolnih organa. $U$ isto to vrijeme pitanja koja su ispitivala interes za tu nastavnu temu ukazali su da su dječaci za spolnost visoko zainteresirani već od petog razreda osnovne škole, dok ih kontrola rađanja i kontracepcija u životnoj dobi osmog razreda ne zanima (Garašić, 2012). Isto je istraživanje pokazalo da djevojčice spolnost počinje zanimati tek u osmom razredu osnovne škole kada im raste i interes za kontrolu rađanja i kontracepciju koji je prisutan još od petog razreda osnovne škole. Dakle učenici pokazuju interes, ali ne i znanje o sadržajima ove teme. Razloge za ovo možemo potražiti u činjenici da pojedini učenici, ali svakako i učitelji biologije osjećaju nelagodu dok pričaju o temama spolnosti te se ova nastavna tema vjerojatno obrađuje na način koji ne pobuđuje interes i ne motivira učenike na usvajanje koncepta. Često su nastavne jedinice u sastavu ove teme obrađene u različitom opsegu ovisno o nastavnikovim kompetencijama i osobnim stavovima, iako su nastavni sadržaji propisani Nastavnim planom i programom (MZOŠ, 2006).

Cilj rada bio je istražiti učestalost pristupanja učenika nastavnim sadržajima biologije i usvajanje obrazovnih ishoda pomoću Moodle sustava, a kroz njegovu implementaciju u nastavi biologije osmog razreda osnovne škole u sklopu nastavne teme "Sastav tijela,, razmnožavanje i razvitak“. Temeljem cilja istraživanja postavljena je hipoteza: ako učenici tijekom pet tjedana učenja češće pristupaju nastavnim sadržajima biologije u sustavu Moodle ostvarit će bolje rezultate na pisanoj provjeri znanja.

\section{MATERIJALI I METODE}

U svrhu istraživanja primijenjen je model eksperimentalnog istraživanja s paralelnim grupama (Cohen, 2007). Kod eksperimenta s paralelnim grupama postoje dvije grupe ispitanika, od kojih je svaka nosilac svog eksperimentalnog faktora: kontrolna grupa poučavala se na tradicionalan način koristeći aktivne metode učenja, a eksperimentalna grupa se poučavala pomoću sustava Moodle.

Kontrolna grupa je nastavu biologije imala utorkom u učionici biologije tijekom blok sata, a eksperimentalna grupa je e-sadržajima iz biologije pristupala istovremeno u učionici informatike, također tijekom blok sata. S njima je u učionici informatike bio učitelj kao tehnička podrške ukoliko im je bila potrebna. Svih pet tjedana istraživanja učenici eksperimentalne grupe nisu imali face to face kontakta sa svojom učiteljicom biologije. S učiteljicom su komunicirali putem sustava Moodle: porukama, forumom, chatom i e-poštom.

Uzorak su činila 48 učenika dva osma razreda jedne gradske osnovne škole. U cilju formiranja kontrolne i eksperimentalne grupe, a unutar svakog razreda, ispitanici su grupirani prema rezultatima provedenog predtesta. Definiranje ekvivalentnih grupa načinjeno je izjednačavanjem u rasponu bodova od \pm 1 . U cilju provjere ekvivalentnosti eksperimentalne i kontrolne skupine: izračunala se aritmetička sredina i varijanca. 
Tablica 1 Struktura jedinica poučavanja u Moodle-u

\begin{tabular}{c}
\hline Jedinice poučavanja oblikovane u sustavu Moodle \\
\hline 1. Građa i uloga spolnih organa \\
2. Začeće i razvitak djeteta prije rođenja \\
3. Životna razdoblja čovjeka: od života do smrti \\
4. Odgovorno spolno ponašanje \\
5. Ponavljanje i provjera znanja \\
\hline
\end{tabular}

Svakoj novoj jedinci poučavanja (tablica 1) učenici eksperimentalne grupe prvi su put pristupali utorkom u učionici informatike, nakon čega su im bile dostupne tijekom cijelog razdoblja istraživanja, bilo u školi bilo od kuće.

Svaka jedinica poučavanja sastojala se od uvodnog dijela u kojem se kroz kratki tekst učenicima dala informacija o cilju nastavnog sata. Zatim su uslijedili moduli koji su odgovarali obrazovnim ishodima za svaku nastavnu jedinicu. Svaki modul sadržavao je tekst koji je bio obogaćen slikovnim prikazima i filmovima. Na kraju svakog modula nalazili su se nizovi zadataka objektivnog tipa u cilju provjere usvojenosti ishoda: zadatci nadopunjavanja, alternativnog izbora, višestrukog izbora te zadatci povezivanja. Učenici su samostalno birali svoju putanju učenja u jedinici poučavanja te su se mogli vraćati modulima i ponovno pristupati rješavanju zadataka objektivnog tipa sve do željenog rezultata riješenosti.

Peta jedinica poučavanja sastojala se dva dijela. U prvom dijelu učenici su mogli pristupiti svim prethodnim jedinicama poučavanja i modulima te nizovima zadataka. $U$ drugom dijelu su pristupili završnoj provjeri znanja kroz niz zadataka objektivnog tipa. Završnoj provjeri znanja mogli su pristupiti samo jednom.

\section{Instrumenti istraživanja}

Istraživanje je provedeno pomoću dva upitnika te testa provjere znanja. Prvi upitnik od 12 čestica zatvorenog tipa (prilog 1) učenici eksperimentalne grupe su rješavali prije početka e-učenja, a imao je za cilj dobiti informaciju o tome što učenici očekuju od e-učenja, kakvu predodžbu imaju o e-učenju, kakva su njihova očekivanja o takvom načinu poučavanja i učenja. Odgovori su bili mogući unutar 5stupanjske skale Likertovog tipa: 1-vrlo malo, 2-malo, 3-umjereno, 4-mnogo, 5-vrlo mnogo.

Drugi upitnik učenici eksperimentalne grupe rješavali su nakon završetka e-učenja, u svrhu provjere učeničkih iskustava o učinkovitosti i zadovoljstvu učenja nastavnih sadržaja pomoću Moodle sustava (prilog 2). Upitnik se sastojao od 11 čestica zatvorenog tipa na koja su odgovori bili mogući unutar 5stupanjske skale Likertovog tipa. Posljednja čestica upitnika bila je otvorenog tipa: „Želim u budući elekcijama iz biologije promijeniti ..." te se od učenika zahtijevalo da sugeriraju, kritiziraju, komentiraju svoje iskustvo učenja sadržaja biologije primjenom sustava Moodle.

Istraživači, kao kreatori nastavnih sadržaja i administratori sustava Moodle, na vrlo jednostavan i pregledan način, uz grafičke prikaze imaju uvid kada je i koliko puta učenik pristupio nekom nastavnom sadržaju. Sustav Moodle bilježi točno vrijeme pristupanja nastavnom sadržaju svakog učenika. Ovi su se podatci u datoteci preuzeli iz sustava Moodle te su se za potrebe istraživanja obradili.

Završna provjera znanja bila je kako po izboru pitanja tako i po broju bodova identična i za eksperimentalnu i za kontrolnu grupu. Završna provjera znanja sastojala se od 21. niza zadataka

Novoselić, D., Bulić, M. 2017. Utjecaj učestalosti pristupanja e-nastavnim sadržajima biologije na usvojenost obrazovnih ishoda. Educ. biol. 3, 1, 127-142. 
objektivnog tipa prve, druge i treće kognitivne razine, a kojima se provjeravalo učenikovo reproduktivno znanje, razumijevanje i primjena te rješavanje problema iz ispitivane nastavne teme. Maksimalno mogući broj bodova iznosio je 27.

Bili su zastupljeni zadaci nadopunjavanja u kojima je u rečenici nedostajala jedna riječ. Drugu skupinu činili su zadaci alternativnog izbora gdje učenik treba prepoznati je li tvrdnja točna ili ne. Treću skupinu činili su zadaci višestrukog izbora. U četvrtoj skupini nalazili su se zadaci povezivanja ujednačenog tipa. Zadaci su se sastojali od uvodne tvrdnje te skupa podataka koje je trebalo međusobno povezati.

\section{Postupci obrade podataka}

Nakon provedenog istraživanja podaci prikupljeni opisanim instrumentima uneseni su u računalni program za statističku obradu SPSS 16 te je izvršen postupak obrade podataka: vrijednost aritmetičke sredine kao mjera centralne tendencije, standardna devijacija za izražavanje odstupanja pojedinog rezultata od aritmetičke sredine, a prosječno kvadratno odstupanje izraženo je kroz varijancu. U cilju utvrđivanja postojanja statističke značajnosti između aritmetičkih sredina čestica upitnika prije i nakon provedenog e-učenja proveden je t-test.

\section{REZULTATI}

Radu učenika na sustavu Moodle prethodilo je oblikovanje baza područnog znanja i oblikovanje nastavnih sadržaja prema ADDIE modelu (Dick i Carey 1996) primjenom specijaliziranih autorskih alata sustava Moodle. Rezultati prvog upitnika o očekivanjima učenja biologije pomoću sustava Moodle prikazani su na slici 1.

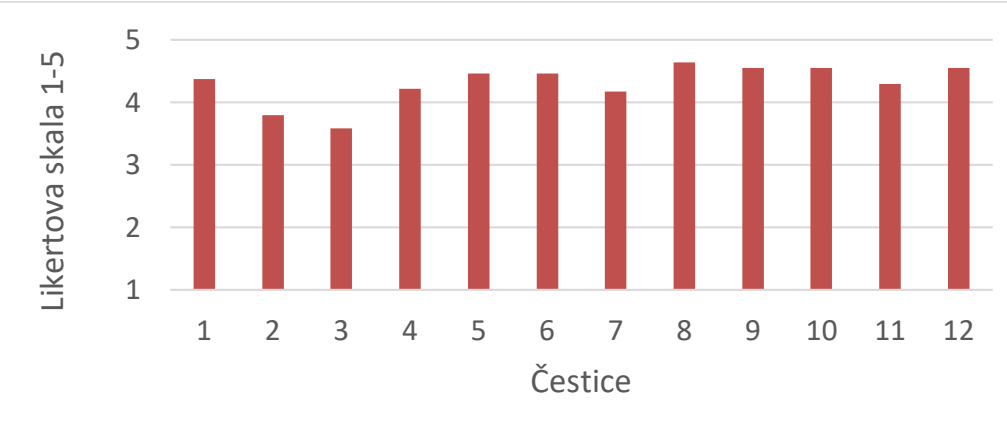

Slika 1 Očekivanja učenika o učenju biologije pomoću sustava Moodle (prilog 1)

Aritmetička sredina prve čestice "Zadovoljan/zadovoljna sam što ću koristit e-učenje iz biologije“ iznosila je 4.37. Ova se čestica odnosila na propitivanje intrinzične motiviranosti učenika za eučenjem biologije. Učenici su iskazali zadovoljstvo što će učiti biologiju pomoću sustava Moodle. Čestica broj dva "Očekujem da će mi e-učenje pomoći u savladavanju odabranog gradiva iz biologije“ imala je aritmetičku sredinu 3.79; standardna devijacija iznosila je 0.932. Učenici su imali različita očekivanja o e-učenju. Čestica tri „Napor koji ću morati uložiti u e-učenje iz biologije bit će ..“ imala je najveću standardnu devijaciju i iznosila je 1.100. Budući da se učenici tijekom svog dosadašnjeg školovanja nisu susreli s e-učenjem, nisu mogli pretpostaviti koliki napor odnosno trud će morati uložiti u e-učenje, stoga je i vrijednost standardne devijacije ove čestice veća. Čestice četiri, pet i šest (prilog 1) imale su aritmetičke sredine od 4.21 do 4.46 te ukazuju da su učenici imali velika očekivanja vezana uz zanimljive zadatke, uvid u uspješnost rješenosti zadataka objektivnog tipa, odnosno broj 
bodova te zanimljivost tekstova. Čestica sedam odnosila se na glavni izbornik „Glavni izbornik bit će jednostavan za korištenje" imala je aritmetičku sredinu 4.17, a vrijednost standardne devijacije iznosila je 0.868. Učenici su imali raznolika očekivanja o preglednosti glavnog izbornika, od onih koji su očekivali malu preglednost do onih koji su očekivali vrlo dobru preglednost. Najvišu vrijednost aritmetičke sredine $(4,63)$ i najmanju standardnu devijaciju $(0,496)$ imala je čestica osam: „Slike će biti jasne i zanimljive". Učenici su imali vrlo visoka očekivanja o slikama koje će biti integralni dio elekcija. Također učenici su očekivali da će e-lekcije sadržavati i filmove (čestica devet). Čestice 10. „Dobit ću upute o e-učenju“ i 11. „Upute o načinu korištenja e-lekcija bit će jasne“ dale su uvid u očekivanja učenika vezanim uz upute za e-učenje. Učenici su očekivali jasne i precizne upute koje će im biti dane kako bi mogli slijediti e-lekcije. Posljednja čestica anketnog upitnika propitivala je učenička očekivanja o zanimljivosti e-učenja u odnosu na tradicionalno poučavanje odnosno učenje. Aritmetička sredina ove čestice iznosila je 4.54. Učenici su očekivali da će e-učenje biti zanimljive u odnosu na tradicionalno e-učenje.

Nakon provedenog e-učenja, a u svrhu provjere učeničkih iskustava o učinkovitosti i zadovoljstvu učenja biologije pomoću sustava Moodle, učenici eksperimentalne grupe učenici su rješavali drugi upitnik (prilog 2). Rezultati su izneseni na slici 2.

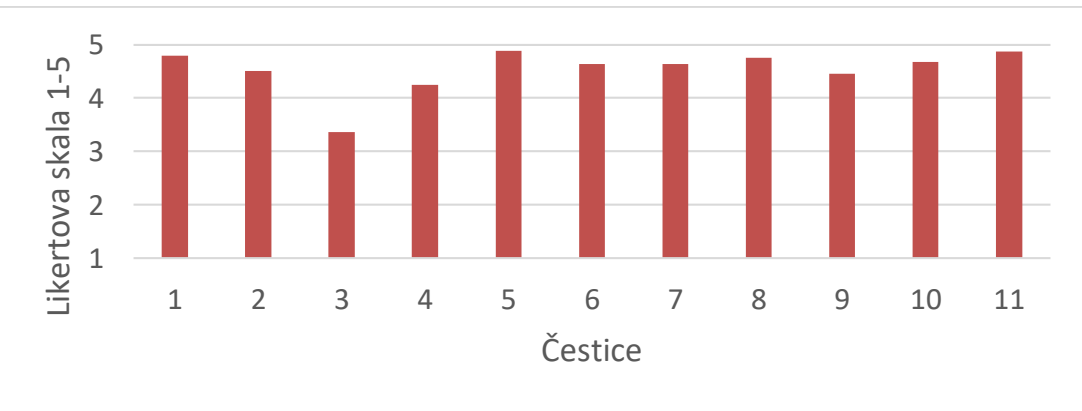

Slika 2 Ispunjena očekivanjima nakon učenja biologije pomoću sustava Moodle (prilog 2)

Prva čestica „Zadovoljan/zadovoljna sam korištenjem e-učenja iz biologije“ imala je veću aritmetičku sredinu u odnosu na istu česticu u upitniku prije istraživanja i iznosila je 4.79. Također je druga čestica „E-učenje mi je pomoglo u savladavanju gradiva iz biologije“ imala veću aritmetičku sredinu u odnosu na istu u upitniku prije istraživanja i iznosila je 4.50. U cilju utvrđivanja postojanja statističke značajnosti između aritmetičkih sredina čestica jedan i dva upitnika prije i nakon provedenog eučenja proveden je t-test. Dobivena Sig. vrijednost manja je od 0.05 što ukazuje da postoji značajna statistička razlika između vrijednosti aritmetičkih sredina ovih dviju čestica prije i nakon istraživanja. Učenici eksperimentalne grupe zadovoljni su e-učenjem i smatraju da im je e-učenje pomoglo u savladavanju gradiva iz biologije. Utvrđena je statistički značajna razlika vrijednosti aritmetičkih sredina prije i nakon istraživanja i to čestice broj 5: „Zadovoljan/zadovoljna sam što imam odmah uvid u ostvareni broj bodova iz e-lekcije. Učenici su izrazili veće zadovoljstvo uvidom u ostvarene rezultate od onoga koji su očekivali prije početka e-učenja. Čestice šest („Tekst e-lekcije bio je lagan i zanimljiv“), sedam („Glavni izbornik bio je jednostavan za snalaženje“) i osam („Slike su bile jasne i zanimljive") upitnika nakon provedenog e-učenja imale su veću vrijednost aritmetičkih sredina u odnosu na iste čestice upitnika prije e-učenja što ukazuje da su ispunjena očekivanja učenika. Filmovi su bili zanimljivi i korisni (čestica 9), a upute o načinu korištenja e-lekcija bile su jasne (čestica 10). Učenici su ocjenom izvrstan ocijenili e-lekcije iz biologije (čestica 11). 
Kako bi se dobio uvid u aktivnost pristupanja nastavnim sadržajima učenika na sustavu Moodle, a tijekom petotjednog razdoblja podaci su iz sustava Moodle preneseni u Microsoft Office Excel 2010 i analizirani. Rezultati su prikazani u tablicama 1 do 5 . Imena i prezimena učenika, a u cilju očuvanja privatnosti, zamijenjena su rednim brojem.

Tablica 2 Aktivnost učenika u prvom tjednu istraživanja

\begin{tabular}{|c|c|c|c|c|c|c|c|}
\hline Učenik & $\begin{array}{c}\text { Ponedjeljak/ } \\
\text { aktivnost }\end{array}$ & $\begin{array}{c}\text { Utorak/ } \\
\text { aktivnost }\end{array}$ & $\begin{array}{c}\text { Srijeda/ } \\
\text { aktivnost }\end{array}$ & $\begin{array}{c}\text { Četvrtak/ } \\
\text { aktivnost }\end{array}$ & $\begin{array}{c}\text { Petak/ } \\
\text { aktivnost }\end{array}$ & $\begin{array}{c}\text { Subota/ } \\
\text { aktivnost }\end{array}$ & $\begin{array}{c}\text { Nedjelja/ } \\
\text { aktivnost }\end{array}$ \\
\hline $\mathbf{1}$ & & 25 & & & & & \\
\hline $\mathbf{2}$ & & 74 & & & & & \\
\hline $\mathbf{3}$ & & 34 & & & & & \\
\hline $\mathbf{4}$ & & 76 & 23 & & & & \\
\hline $\mathbf{5}$ & & 20 & 10 & & & & \\
\hline $\mathbf{6}$ & & 86 & & & & & \\
\hline $\mathbf{7}$ & & 50 & 3 & & & & \\
\hline $\mathbf{8}$ & & 62 & & & & & \\
\hline $\mathbf{9}$ & & 71 & & & & & \\
\hline $\mathbf{1 0}$ & & 85 & 23 & & & & \\
\hline $\mathbf{1 1}$ & & 86 & & & & & \\
\hline $\mathbf{1 2}$ & & 80 & & & & & \\
\hline $\mathbf{1 3}$ & & 66 & 7 & & & & \\
\hline $\mathbf{1 4}$ & & 127 & 3 & & & & \\
\hline $\mathbf{1 5}$ & & 105 & 7 & & & & \\
\hline $\mathbf{1 6}$ & & 77 & & & & & \\
\hline $\mathbf{1 7}$ & & 222 & & & & & \\
\hline $\mathbf{1 8}$ & & 114 & & & & & \\
\hline $\mathbf{1 9}$ & & 91 & & & & & \\
\hline $\mathbf{2 0}$ & & 82 & 8 & & & & \\
\hline $\mathbf{2 1}$ & & 137 & & & & & \\
\hline $\mathbf{2 2}$ & & 142 & 39 & & & & \\
\hline $\mathbf{2 3}$ & & 129 & 42 & & & & \\
\hline $\mathbf{2 4}$ & & 118 & & & & & \\
\hline
\end{tabular}

Prvi dan (ponedjeljak) prvoga tjedna istraživanja učenicima su podijeljene lozinke za pristup nastavnim sadržajima u sustavu Moodle i bili su instruirani od strane učiteljice o načinu korištenja sustava Moodle. Upravo stoga u tablici 2. prvi dan prvoga tjedna nema prikazane aktivnosti učenika. Nastavnim sadržajima učenici su mogli prvi puta pristupiti tek u utorak kada je učiteljica dozvolila pristup učenicima, iako su sadržaji bili postavljeni ranije. Slijedeći dan, u srijedu, desetak je učenika pristupalo nastavnim sadržajima iz svojih kuća, a od toga je zabilježeno 59 aktivnosti učenika 8.a razreda i znatno više aktivnosti učenika 8.b razreda (106). Učenici su pregledavali sadržaj nastavne lekcije prethodnog dana te sudjelovali u diskusiji na forumu pri čemu su se zahvalili učiteljicamavoditeljima projekta na samom projektu. Nažalost u danima koji slijede, s izuzetkom jednog učenika, učenici se nisu prijavili u sustav Moodle.

$\mathrm{U}$ drugom tjednu istraživanja (tablica 3), učenicima je nova e-lekcija bila otvorena za pristup ponovo u utorak. Samo je jedan učenik pristupio sadržajima dan prije e-nastave. U samo četiri minute pregledao je mali dio prethodne lekcije kao i niz zadataka objektivnog tipa koji su se rješavali nakon završene lekcije. Nakon nastave u informatičkoj učionici, $u$ danima do kraja tog tjedna, svega je pet učenika od ukupno 24 i to s vrlo malom aktivnošću posjetilo sustav Moodle s nastavnim sadržajima. U tim je danima samo učenica pod brojem 22 pregledala sadržaje koji su se odnosili na prvu i drugu nastavnu lekciju. 
I u trećem tjednu istraživanja novoj e-lekciji su učenici eksperimentalne grupe, radeći u sustavu Moodle u informatičkoj učionici, mogli pristupiti u utorak. Samo je pet učenika pregledao sadržaje dan prije nastave u učionici (tablica 4). Učenik pod brojem 21 pregledao je vrlo temeljito sve do toga dana odrađene lekcije. Taj je učenik na završnoj provjeri znanja ostvario izvrstan rezultat.

Tablica 3 Aktivnost učenika u drugom tjednu istraživanja

\begin{tabular}{|c|c|c|c|c|c|c|c|}
\hline Učenik & $\begin{array}{c}\text { Ponedjeljak/ } \\
\text { aktivnost }\end{array}$ & $\begin{array}{c}\text { Utorak/ } \\
\text { aktivnost }\end{array}$ & $\begin{array}{c}\text { Srijeda/ } \\
\text { aktivnost }\end{array}$ & $\begin{array}{c}\text { Četvrtak/ } \\
\text { aktivnost }\end{array}$ & $\begin{array}{c}\text { Petak/ } \\
\text { aktivnost }\end{array}$ & $\begin{array}{c}\text { Subota/ } \\
\text { aktivnost }\end{array}$ & $\begin{array}{c}\text { Nedjelja/ } \\
\text { aktivnost }\end{array}$ \\
\hline $\mathbf{1}$ & & 54 & & & & & \\
\hline $\mathbf{2}$ & & 94 & & & & & \\
\hline $\mathbf{3}$ & & 43 & & & & & \\
\hline $\mathbf{4}$ & & 54 & & & & & \\
\hline $\mathbf{5}$ & 8 & 76 & 5 & & & & \\
\hline $\mathbf{6}$ & & 96 & & & & & \\
\hline $\mathbf{7}$ & & 93 & & & & & \\
\hline $\mathbf{8}$ & & 86 & & & & & \\
\hline $\mathbf{9}$ & & 81 & & & & & \\
\hline $\mathbf{1 0}$ & & 82 & & & & & \\
\hline $\mathbf{1 1}$ & & 38 & & & & & \\
\hline $\mathbf{1 2}$ & & 147 & 3 & & & & \\
\hline $\mathbf{1 3}$ & & 80 & & 22 & & & \\
\hline $\mathbf{1 4}$ & & 80 & & & & & \\
\hline $\mathbf{1 5}$ & & 54 & & & & & \\
\hline $\mathbf{1 6}$ & & 105 & & & & & \\
\hline $\mathbf{1 7}$ & & 74 & & & & & \\
\hline $\mathbf{1 8}$ & & 62 & & & & & \\
\hline $\mathbf{1 9}$ & & 106 & & & & & \\
\hline $\mathbf{2 0}$ & & 109 & & 9 & & & \\
\hline $\mathbf{2 1}$ & & 57 & & & & & \\
\hline $\mathbf{2 2}$ & & 79 & & & & & \\
\hline $\mathbf{2 3}$ & & 87 & & & & & \\
\hline $\mathbf{2 4}$ & & & & & & & \\
\hline
\end{tabular}

Tablica 4 Aktivnost učenika u trećem tjednu istraživanja

\begin{tabular}{|c|c|c|c|c|c|c|c|}
\hline Učenici & $\begin{array}{c}\text { Ponedjeljak/ } \\
\text { aktivnost }\end{array}$ & $\begin{array}{c}\text { Utorak/ } \\
\text { aktivnost }\end{array}$ & $\begin{array}{c}\text { Srijeda/ } \\
\text { aktivnost }\end{array}$ & $\begin{array}{c}\text { Četvrtak/ } \\
\text { aktivnost }\end{array}$ & $\begin{array}{c}\text { Petak/ } \\
\text { aktivnost }\end{array}$ & $\begin{array}{c}\text { Subota/ } \\
\text { aktivnost }\end{array}$ & $\begin{array}{c}\text { Nedjelja/ } \\
\text { aktivnost }\end{array}$ \\
\hline $\mathbf{1}$ & & 44 & & & & & \\
\hline $\mathbf{2}$ & 2 & 63 & & & & & \\
\hline $\mathbf{3}$ & & 8 & & & & & \\
\hline $\mathbf{4}$ & & 60 & & & & & \\
\hline $\mathbf{5}$ & & 59 & & & & & \\
\hline $\mathbf{6}$ & & 82 & & & & & \\
\hline $\mathbf{7}$ & & 72 & & & & & \\
\hline $\mathbf{8}$ & & 77 & & & & & \\
\hline $\mathbf{9}$ & & 100 & & & & & \\
\hline $\mathbf{1 0}$ & & 56 & & & & & \\
\hline $\mathbf{1 1}$ & & 38 & & & & & \\
\hline $\mathbf{1 2}$ & & 50 & & & & & \\
\hline $\mathbf{1 3}$ & 3 & 60 & & & & & \\
\hline $\mathbf{1 4}$ & & 81 & & & & & \\
\hline $\mathbf{1 5}$ & 27 & 65 & & & & & \\
\hline $\mathbf{1 6}$ & & 54 & & & & & \\
\hline $\mathbf{1 7}$ & & 120 & & & & & \\
\hline $\mathbf{1 8}$ & & 64 & & & & & \\
\hline $\mathbf{1 9}$ & & 66 & & & & & \\
\hline $\mathbf{2 0}$ & & 110 & & & & & \\
\hline $\mathbf{2 1}$ & 77 & 90 & & & & & \\
\hline $\mathbf{2 2}$ & & 132 & & & & & \\
\hline $\mathbf{2 3}$ & 40 & 81 & 10 & 7 & & & \\
\hline $\mathbf{2 4}$ & & 61 & & & & & \\
\hline
\end{tabular}

Novoselić, D., Bulić, M. 2017. Utjecaj učestalosti pristupanja e-nastavnim sadržajima biologije na usvojenost obrazovnih ishoda. Educ. biol. 3, 1, 127-142. 
U četvrtom tjednu samo su tri učenika pristupila sadržajima na sustavu Moodle dan prije e-nastave (tablica 5). U danima nakon nastave, svega je pet učenika od ukupno 24 i to s vrlo malom aktivnošću posjetilo sustav Moodle s nastavnim sadržajima. $U$ tom je tjednu u nedjelju nastavnim sadržajima pristupilo šest učenika. Imali su znatno veću aktivnost i broj pregledanih nastavnih sadržaja.

Tablica 5 Aktivnost učenika u četvrtom tjednu istraživanja

\begin{tabular}{|c|c|c|c|c|c|c|c|}
\hline Učenik & $\begin{array}{c}\text { Ponedjeljak/ } \\
\text { aktivnost }\end{array}$ & $\begin{array}{c}\text { Utorak/ } \\
\text { aktivnost }\end{array}$ & $\begin{array}{c}\text { Srijeda/ } \\
\text { aktivnost }\end{array}$ & $\begin{array}{c}\text { Četvrtak/ } \\
\text { aktivnost }\end{array}$ & $\begin{array}{c}\text { Petak/ } \\
\text { aktivnost }\end{array}$ & $\begin{array}{c}\text { Subota/ } \\
\text { aktivnost }\end{array}$ & $\begin{array}{c}\text { Nedjelja/ } \\
\text { aktivnost }\end{array}$ \\
\hline $\mathbf{1}$ & & 13 & & & & & \\
\hline $\mathbf{2}$ & & 64 & & & & & \\
\hline $\mathbf{3}$ & & 73 & & & & & \\
\hline $\mathbf{4}$ & & 54 & & & & & \\
\hline $\mathbf{5}$ & & 63 & & & & & \\
\hline $\mathbf{6}$ & & 78 & & & & & \\
\hline $\mathbf{7}$ & & 90 & & & & & \\
\hline $\mathbf{8}$ & & 68 & & 30 & & & 107 \\
\hline $\mathbf{9}$ & & 105 & & & & & 174 \\
\hline $\mathbf{1 0}$ & & 102 & & & & & \\
\hline $\mathbf{1 1}$ & & 80 & & & & 1 & 146 \\
\hline $\mathbf{1 2}$ & & 116 & & & & & \\
\hline $\mathbf{1 3}$ & & 68 & & & & & \\
\hline $\mathbf{1 4}$ & & 63 & & & & & \\
\hline $\mathbf{1 5}$ & 6 & 65 & & & & & \\
\hline $\mathbf{1 6}$ & & 53 & & & 8 & 32 & \\
\hline $\mathbf{1 7}$ & & 94 & & & & & \\
\hline $\mathbf{1 8}$ & & 99 & & & & & \\
\hline $\mathbf{1 9}$ & 10 & 63 & & & & & \\
\hline $\mathbf{2 0}$ & & 75 & & & & 17 & \\
\hline $\mathbf{2 1}$ & 2 & 98 & & & & & \\
\hline $\mathbf{2 2}$ & & 80 & & & & & \\
\hline $\mathbf{2 3}$ & & 92 & & 39 & 9 & & \\
\hline $\mathbf{2 4}$ & & 83 & & & & & \\
\hline
\end{tabular}

U posljednjem tjednu istraživanja (tablica 6), učenici su imali nastavu u informatičkoj učionici ponovno u utorak, kada su jedan školski sat proveli pregledavajući nastavne sadržaje u sustavu Moodle, a drugi školski sat imali su provjeru znanja koja je također bila postavljena u sustavu Moodle.

Tablica 6 Aktivnost učenika u petom tjednu istraživanja

\begin{tabular}{|c|c|c|c|c|c|c|c|}
\hline Učenici & $\begin{array}{c}\text { Ponedjeljak/ } \\
\text { aktivnost }\end{array}$ & $\begin{array}{c}\text { Utorak/ } \\
\text { aktivnost }\end{array}$ & $\begin{array}{c}\text { Srijeda/ } \\
\text { aktivnost }\end{array}$ & $\begin{array}{c}\text { Četvrtak/ } \\
\text { aktivnost }\end{array}$ & $\begin{array}{c}\text { Petak/ } \\
\text { aktivnost }\end{array}$ & $\begin{array}{c}\text { Subota/ } \\
\text { aktivnost }\end{array}$ & $\begin{array}{c}\text { Nedjelja/ } \\
\text { aktivnost }\end{array}$ \\
\hline $\mathbf{1}$ & 181 & 7 & & & & & \\
\hline $\mathbf{2}$ & 123 & 10 & & & & & \\
\hline $\mathbf{3}$ & & 11 & & & & & \\
\hline $\mathbf{4}$ & & 9 & & & & & \\
\hline $\mathbf{5}$ & & 18 & & & & & \\
\hline $\mathbf{6}$ & & 103 & & & & & \\
\hline $\mathbf{7}$ & 19 & 31 & & & & & \\
\hline $\mathbf{8}$ & 102 & 33 & & & & & \\
\hline $\mathbf{9}$ & 41 & 29 & & & & & \\
\hline $\mathbf{1 0}$ & & 10 & & & & & \\
\hline $\mathbf{1 1}$ & 147 & 143 & & 3 & & & \\
\hline $\mathbf{1 2}$ & 81 & 44 & & & & & \\
\hline $\mathbf{1 3}$ & & 10 & & & & & \\
\hline $\mathbf{1 4}$ & 142 & 17 & & & & & \\
\hline $\mathbf{1 5}$ & 24 & 28 & & & & & \\
\hline $\mathbf{1 6}$ & & 96 & & & & & \\
\hline $\mathbf{1 7}$ & 29 & 54 & & & & 3 & \\
\hline $\mathbf{1 8}$ & 27 & 57 & & & & 1 & \\
\hline $\mathbf{1 9}$ & 67 & 14 & & & & & \\
\hline $\mathbf{2 0}$ & 9 & 33 & & & & & \\
\hline
\end{tabular}

Novoselić, D., Bulić, M. 2017. Utjecaj učestalosti pristupanja e-nastavnim sadržajima biologije na usvojenost obrazovnih ishoda. Educ. biol. 3, 1, 127-142. 


\begin{tabular}{|l|c|c|l|l|l|l|l|}
\hline $\mathbf{2 1}$ & 180 & 9 & & & & & 2 \\
\hline $\mathbf{2 2}$ & & 30 & & & & & \\
\hline $\mathbf{2 3}$ & 41 & 45 & & & & 1 & \\
\hline $\mathbf{2 4}$ & 35 & 53 & & & & & \\
\hline
\end{tabular}

Zabilježena je značajna aktivnost učenika u ponedjeljak, dan prije provjere znanja. No, bilo je učenika koji nisu niti toga dana pristupili sustavu (tablica 5). Učenik 3 iako nije pristupio sustavu niti je bio aktivan tijekom cijelog istraživanja, na završnoj provjeri ostvario je vrlo dobar rezultat i riješio je $89,6 \%$ zadataka. Učenik 4 tijekom cijelog istraživanja rijetko je pristupao sustavu, ali je riješio više od $90 \%$ zadatka. Učenik 5 tijekom cijelog istraživanja postizao je slabe rezultate, izvan učionice gotovo da i nije pristupao sadržajima te je u konačnici ostvario jedva prolazan rezultat. Učenici 6,16 i 22 također nisu pristupali sadržajima na Moodle-u, osim u razdoblju održavanja e-nastave, ali su ostvarili vrlo dobar rezultat na završnom testu.

Tijekom istraživanja, a nakon uočene slabije aktivnosti učenika i njihovog pristupanja sustavu, istraživači su prije nastavnog sata četvrtog tjedna u sustav Moodle na forum postavili problemski zadatak. Zabilježeno je za učenike 8a ukupno 3 zapisa za pregled foruma "Dokažite tvrdnju“; za učenike $8 \mathrm{~b}$ zabilježeno je ukupno 39 zapisa za pregled tog foruma i tri su učenika ponudila odgovor. lako su nastavnici na forumu poticali učenike na promišljanje o problemskom zadatku, povratna reakcija je izostala. Do kraja istraživanja niti jedan učenik nije ponudio točno rješenje problemskog zadataka. Nije utvrđena statistički značajna razlika u aritmetičkim sredinama rezultata završne pismene provjere znanja eksperimentalne i kontrolne grupe. Pojedini učenici eksperimentalne grupe postigli su izvrstan rezultat na pisanoj provjeri znanja iako nisu nakon obrade nastavnih sadržaja pristupali ponovo tim e-sadržajima, što može upućivati kako su u procesu učenja koristili druge izvore znanja osim e-sadržaja postavljenih na Moodle platformu. Učenici koji su učestalo pristupali nastavnim sadržajima postavljenim na Moodle sustavu postigli su vrlo dobar i izvrstan rezultat na pisanoj provjeri znanja što govori u prilog hipotezi ako učenici pristupaju učestalo nastavnim sadržajima iz biologije u sustavu e Moodle, ostvarit će bolji rezultat na pisanoj provjeri znanja.

\section{RASPRAVA}

Provodeći istraživanja učeničkog interesa za školski predmet biologiju, Hidi i Andersen (1992) utvrdili su da se radi o kombinaciji individualnih interesa za područje biologije, kratkoročnih interesa za pojedine teme, što je posljedica zanimljivosti poučavanja u smislu interesa pobuđenog situacijom te socijalnog ozračja na satovima biologije. Nastavna tema "Sastav tijela, razmnožavanje i razvitak" upoznaje učenike s građom spolnih organa, razmnožavanjem te odgovornim spolnim ponašanjem. Rezultati istraživanja (Garašić 2012) ukazali su da učenici te dobi pokazuju veliki interes za ove sadržaje. Isto je u svojim istraživanjima utvrdio i Reiss (2000). Simon (2000), Hoffman, (2002) i Osborne I SUR. (2003) ističu kako se interes učenika u području prirodoslovlja može potaknuti na različite načine, odnosno da različiti aspekti nastave mogu učenika privući: konkretno gradivo te metode poučavanja i korištenje informacijsko-komunikacijske tehnologije. Stoga je za ovo istraživanje upravo odabrana nastavna tema "Sastav tijela, razmnožavanje i razvitak" za čije poučavanje se koristio sustav Moodle.

Jedna od najvažnijih komponenti koja djeluje na ishode učenja je motivacija. Motivacija se u kontekstu socijalno-kognitivne teorije definira kao stanje u kojem smo iznutra pobuđeni na određeno ponašanje usmjereno prema postizanju nekog cilja (Rheinberg, 2004). Motivirani učenici uspješno 
savladavaju nastavne sadržaje jer primjenjuju određena ponašanja: uče, aktivni su tijekom nastavnog sata, postavljaju pitanja, izvode pokuse, uključuju se u projekte. Sanfeliz i Stalzer (2003) u svom radu iznose kako je najvažnija odrednica učiteljske zadaće s učenicima upravo u poticanju motivacije za učenje. Motivirani učenici uživaju učeći prirodoslovlje, vjeruju u svoje sposobnosti i odgovorno se odnose prema učenju. Učenici eksperimentalne grupe u prvoj čestici upitnika iskazali su veće zadovoljstvo od očekivanog korištenjem sustava Moodle u učenju biologije, a što potvrđuju vrijednosti aritmetičkih sredina kao i vrijednost t-testa. Možemo zaključiti da su učenici bili intrinzično motivirani za usvajanjem sadržaja iz biologije pomoću sustava Moodle. Intrinzična motivacija odgovor je na unutarnju učenikovu potrebu za učenjem, a proizlazi iz radoznalosti, potrebe za znanjem biologije, osjećaja kompetencije; procjena vlastite uspješnosti proizlazi iz učeničkog uvjerenja da ima utjecaj na svoj uspjeh u učenju te je svojim postupcima u stanju ostvariti željeni cilj (Pajares i Schunk, 2001; Pintrich, 2003). U prvom tjednu istraživanja učenici su nastavnim sadržajima pristupili u utorak. Deset intrinzično motiviranih učenika pristupilo je nastavnim sadržajima od kuće i dan nakon što su nastavu imali u informatičkoj učionici. Jedan od razloga slabe aktivnosti učenika tijekom cijelog razdoblja istraživanja možemo potražiti i u nezadovoljstvu koje su učenici iskazali s obzirom na činjenicu da su bili registrirani u sustav punim imenom i prezimenom, a ne nadimkom, koji često koriste pri kreiranju svojih profila na društvenim mrežama kao i informacijom s kojom su ih učitelji/istraživači upoznali: da kao administratori sustava imaju uvid u sve njihove aktivnosti u sustavu Moodle.

Jedna od prednosti rada u sustavu Moodle svakako je istovremena povratna informacija učenika o rezultatima njegova rada, a što utječe na ekstrinzičnu motivaciju učenika. Naime ekstrinzična motivacija učenika svoj izvor ima izvan učenika, primjerice dobar rezultat na testu, ocjene, učiteljičina pohvala, diploma, medalja i druge nagrade (Vizek-Vidović i sur., 2003; Rheinberg, 2004). Ponašanje se označava ekstrinzično motiviranim ako pokretač ponašanja leži izvan same radnje ili šire formulirano: ako se osobom upravlja izvana Ekstrinzična motivacija povezuje uspješno izvođenje zadataka $s$ posljedicama do kojih je učenicima stalo. Temelji se na potkrepljenjima, povratnim informacijama, nagradama. Posljedica koju učenici najviše žele su dobre ocjene. Za školsko okruženje posebno značenje ima motiv za postignućem: učenici imaju očekivanja vezana uz uspješnost te percepciju vrijednosti cilja. Ovo potvrđuju Atkinson i sur. (1978) prema kojima su ključni pokretači ljudskog ponašanja potreba za postignućem, druženjem, samostalnošću i dr. Atkinson smatra da se motiv za postignućem odnosi na želju da zadatak obavimo što bolje možemo. Učenici su u upitnicima izrazili zadovoljstvo uvidom u ostvarene rezultate koje im omogućuje sustav Moodle. Takvo zapažanje u skladu je s rezultatima istraživanja Vizek-Vidović i sur. (2003) i Rheinberg (2004) koja ukazuju da je davanje povratne informacije (uvid u ostvareni broj bodova) izuzetno važno za učenike jer djeluje pozitivno na motivaciju za postignućem. Važnost brzog uvida u povratnu informaciju naglašavaju i Eccles i Wiegfeld (1985) te ističu da je glavni činitelj motiva za postignućem očekivanja uspjeha povezan s procjenom vlastitih sposobnosti i vrijednosti zadatka, u ovom slučaju e-učenja.

Učenici se na različite načine pripremaju za zadatke koji ih očekuju u školi, bilo da se radi o usustavljivanju ili provjeravanju znanja: koriste udžbenike, zabilješke u svojim bilježnicama, vježbaju odgovarati na pitanja. Svi ti načini imaju za cilj povećati uspjeh na provjeri znanja. Istraživanja koje su proveli Semb, Hopkins i HursH (1973) te Bostow i O'Connor (1973) ukazala su da učenici postižu bolje razultate ako za usustavljivanje znanja i vježbu, a prije pisane provjere znanja, koriste pripremljeni 
materijali ili testove s pitanjima koja se odnose na nastavne sadržaje čija će se usvojenost provjeravati pisanom provjerom. Nastavni sadržaji koji su bili kreirani u sustavu Moodle omogućavali su učenicima pristup u bilo kojem trenutku tijekom razdoblja istraživanja. Pojačana aktivnost učenika odnosno pregledavanje nastavnih sadržaja u sustavu Moodle zabilježena je u prvom danu posljednjeg tjedna istraživanja (ponedjeljak). Učenici su se pripremali za provjeru znanja koja im je bila najavljena za utorak u informatičkoj učionici, a s ciljem povećanja uspjeha. Priprema učenika za provjere znanja može biti redovita ili će biti odgođena dan prije najavljene provjere. Takav model ponašanja odgode učenja nazvan prokrastinacija opisuju i Born i Davis (1974), Michael (1991) i Poppen (1982). Nastavna je praksa da se datum provedbe provjere znanja najavljuje učenicima dovoljno unaprijed. To je bio slučaj i tijekom provedenog istraživanja.

lako postoje iznimke (Morris, Surber i Bijou 1978) rezultati provjere znanja onih učenika koji se ponašaju prema modelu prokrastinacije, značajno su slabiji od onih učenika koji se pripremaju redovito (Ariely i Wertenbroch 2002; Lloyd i Knutzen 1969; Mawhinney, Bostow, Laws, Blumenfeld i Hopkins 1971). U završnoj provjeri znanja učenici označeni brojem 8, 9, 11, 13 i 14, a koji su pristupili sustavu Moodle i započeli s ponavljanjem, ostvarili su najviše rezultate u završnoj provjeri znanja stoga se može pretpostaviti da im je pristupanje sadržajima i njihovo ponavljanje pomoglo u postizanju boljih rezultata na zadacima za provjeru znanja. Rezultati istraživanja Lamwers i Jazwinski (1989) ukazali su da kada se učenicima ponude češći rokovi provjere znanja, smanjuje se prokrastinacija te se povećava uspjeh provjere znanja, nego kada učenici sami organiziraju dinamiku pripreme učenja za provjeru znanja. lako su učenicima eksperimentalne grupe bile ponuđene $i$ dostupne provjere znanja u sustavu Moodle tijekom cjelokupnog razdoblja istraživanja, nisu im pristupali često te možemo zaključiti da prokrastinacija nije smanjena. Za one učenike koji su izvan informatičke učionice rijetko ili nikada pristupali nastavnim sadržajima u sustavu Moodle, a ostvarili visoki postotak rješenosti provjere znanja, može se pretpostaviti da su nastavne sadržaje usvajali i u učenju koristili propisani tiskani udžbenik i radnu bilježnicu.

lako je odabrana nastavna tema koja pobuđuje interes učenika (Garašić 2012), jer se svojim sadržajima odnosti na same ispitanike, a učenici su iskazali zadovoljstvo rada na nastavnim sadržajima u sustavu Moodle, rijetko su samostalno pristupali nastavnim sadržajima. Možda razloge tomu treba potražiti u koncepciji e-jedinica poučavanja koje nisu učenike stavile u centar nastavnog procesa. Kroz kreirane sadržaje u sustavu Moodle učenici nisu imali prilika samostalno osmišljavati sadržaje i zadatke. Učenici su slijedili zadani sadržaj i rješavali zadatke što odgovara dominantnom pristupu obrazovanja koji je usmjeren na transmisiju znanja i orjentaciju na sadržaj. $U$ zadnjih pedesetak godina dogodile su se dramatične promjene u konceptualizaciji znanosti, ali $i$ konceptualizaciji učenja i metodike poučavanja znanosti (Grandy i Duschl, 2007). Kao posljedica tih promjena, u svim obrazovnim sustavima izrazito jača interes za istraživačkim učenjem kao obrazovnim pristupom koji stavlja učenike u poziciju provođenja „pravih“ istraživanja kakva prakticiraju znanstvenici kad stvaraju novo znanje (Kuhn, 2005). Vrijednost takvog pristupa očituje se $i \mathrm{u}$ tome što sudjelovanje $u$ istraživačkim aktivnostima potiče prirodnu znatiželju, promovira znanstvenu aktivnost kao intelektualnu vrijednost i potkrepljuju gledanje na svijet i prirodne $i$ društvene pojave kao na fenomene koji se mogu zahvatiti na istraživački način (Keselman i Kuhn, 2002). 
Istraživačko učenje u računalnom okruženju za učenike je motivirajuće, izazovno i poticajno, te upućuje na potrebu šire uporabe računalne tehnologije u procesu školskog učenja i poučavanja u području znanosti. Korištenje računalne tehnologije je posebice važno jer pomaže uspostavi kvalitetnog istraživačkog učenja. Ono uvodi učenike u aktivnosti koje oponašaju metode znanstvenog istraživanja, pruža im mogućnost sudjelovanja u aktivnostima koje su inače izvan dosega i osigurava stjecanje znanja o području uz istovremeno razvijanje istraživačkih vještina i učenje o prirodi i procesima znanosti. Stoga bi u budućim istraživanjima učenja biologije pomoću sustava Moodle trebalo koncipirati sadržaje i module na način da od učenika zahtijevaju istraživačko učenje.

\section{ZAKLUUČAK}

Istraživanje je provedeno u razdoblju od pet tjedana s učenicima dva osma razreda jedne gradske osnovne škole. Svako je razredno odjeljenje podijeljeno temeljem rezultata inicijalnog testa te statistički ujednačeno; dok je eksperimentalna grupa radila u informatičkoj učionici s jednim nastavnikom, $u$ isto je vrijeme kontrolna grupa radila nastavu na tradicionalni način $s$ drugim nastavnikom. Učenici eksperimentalne grupe iskazali su veliko zadovoljstvo sudjelovanjem u eučenju, kako prije samog početka tako i na njegovom kraju, a što potvrđuju rezultati provedenih anketnih upitnika. Učenici koju su češće pristupali nastavnom sadržaju, ostvarili su bolji rezultat na ispitu znanja. Unatoč iskazanom interesu i zadovoljstvu, izostao je, od strane istraživača očekivan, veći interes odnosno češće pristupanje sustavu Moodle-a i nastavnim sadržajima. Dinamika pristupanja sustavu odgovarala je modelu koji opisuju i nastavnici tijekom tradicionalne nastave: učenje nastavnih sadržaja dan do dva prije najavljene provjere znanja.

\section{METODIČKI ZNAČAJ}

Kreirani sadržaji u sustavu Moodle nisu učenike stavili u centar nastavnog procesa te nisu imali prilika samostalno osmišljavati sadržaje i zadatke, već su slijedili sadržaj i rješavali zadatke koji su slijedili tradicionalne oblike poučavanja s manjom razinom interaktivnosti, što se treba nastojati unaprijediti pri izradi nastavnih sadržaja za e-učenje u budućnosti.

\section{LITERATURA}

Ariely, D., \& Wertenbroch, K. 2002. Procrastination,deadlines, and performance. Self-control by precommitment. Psychological Science, 13, 219-224.

Atkinson, J.W., Raynor, J.O. 1978. Motivation and achievement. New york, Wiley.

ASTD 2001. A Vision of E-learning for America's Workforce. Report of the Commission on Technology and Adult Learning, http://www.astd.org

Born, D. G., \& Davis, M. L. 1974. Amount and distribution of study in a personalized instruction course and in a lecture course. Journal of Applied Behavior Analysis, 7, 365-375.

Bostow, D. E., \& O'Connor, R. J. 1973. A comparison of two college classroom testing procedures: Required remediation versus no remediation. Journal of Applied Behavior Analysis, 6, 599-607.

Braš Roth, M., Gregurović, M., Markočić Dekanić, A., Markuš, M. 2008. PISA 2006, Prirodoslovne kompetencije za život. Nacionalni centar za vanjsko vrednovanje obrazovanja - PISA centar, Zagreb.

Cohen, L., Manion, L., Morrison, K. 2007. Metode istraživanja u obrazovanju. Naklada Slap, Jastrebarsko.

De Corte, E. 2000. Marrying theory building and improvement of school practice: A permanent challenge for instructional pshychology. Learning and Instruction, 10, 249-266.

Dick, W., Carey, L. 1996. The Systematic Design of Instruction (4th Ed.). New York: Haper Collins College Publishers.

Dikmenli, M. 2010. Misconception of cell division held by student teacher in biology: A drawing analysis. Scientific Research and essay, 5, 2, 235-247

Eccles, J., Wigfield, A. 1985. Teacher expectations and student motivation. U: Vidović, V. V., Rijavec, M., Štetić-Vlahović, V., Miljković, D. 2003. Psihologija obrazovanja. Zagreb: IEP-VERN.

Garašić, D. 2012. Primjerenost biološkog obrazovanja u vertikali osnovnog i gimnazijskog školovanja. Doktorska disertacija. Zagreb: Prirodoslovno-matematički fakultet, 389 str.

Glasser, W. 1994. Kvalitetna škola. Educa. Zagreb.

Novoselić, D., Bulić, M. 2017. Utjecaj učestalosti pristupanja e-nastavnim sadržajima biologije na usvojenost obrazovnih ishoda. Educ. biol. 3, 1, 127-142. 
Grandy, R. i Duschl, R.A. 2007. Reconsidering the Character and Role of Inquiry in School Science: Analysis of a Conference. Science \& Education, 16, 141-166.

Grubišić, A. 2007. Vrednovanje učinka inteligentnih sustava e-učenja. Magistarski rad. Split: Prirodoslovno-matematički fakultet, 195 str.

Hoffman, L. 2002. Promoting girls' interest and achievement in physics classes for beginners. Learning and Instruction, 12 , 447-465

Keselman, A. i Kuhn, D. 2002. Facilitating Self-Directed Experimentation in the Computer Environment. Preuzeto s: http://citeseer.ist.psu.edu/509879.html

Khan, B. H. 2001. A framework for Web-based learning. In: Khan, B.H.(ur): Web-based training. Englewood Cliffs, NJ: Educational Technology Publications

Kuhn, D. 2005. Education for Thinking. Cambridge, MA: Harvard University Press.

Lamwers, L. L., \& Jazwinski, C. H. 1989. A comparison of three strategies to reduce student procrastination in PSI. Teaching of Psychology, 16, 8-12,

Lloyd, K. E., \& Knutzen, N. J. 1969. A self-paced undergraduate course in the experimental analysis of behavior. Journal of Applied Behavior Analysis, 2,125-133.

Mawhinney, V. T., Bostow, D. E., Laws, D. R.,Blumenfeld, G. J., \& Hopkins, B. L. 1971. Acomparison of students studyingbehavior producedby daily, weekly, and three-week testing schedules.Journal of Applied Behavior Analysis, 4,257-264.

Michael, J. 1991. A behavioral perspective on college teaching. The Behavior Analyst, 14, 229-239.

Morris E.K, Surber C.F, Bijou S.W. 1978. Self- versus instructor-pacing: Achievement, evaluations, and retention. Journal of Educational Psychology.70, 224-230.

MZOŠ 2006. Nastavni plan i program za osnovnu školu. Ministarstvo znanosti, obrazovanja i sporta. Zagreb.

MZOŠ 2011. Nacionalni okvirni kurikulum za predškolski odgoj i obrazovanje te opće obvezno i srednjoškolsko obrazovanje. Ministarstvo znanosti, obrazovanja i sporta, Zagreb.

Orion, N., Hofstein, A., Tamir, P., Giddings, G. J. 1997. Development and validation of an instrument for assessing the learning environment of outdoor science activities. Science Education, 81(2), 161-171.

Osborne, J., Simon, S., Collins, S. 2003. Attitude towards science: a review of the literature and its implica-tions. International JournalofScienceEducation, 25, 9, 1049-1079.

Pajares, F., Schunk, D. H. 2001. Self-neliefes and school succes: Self-efficacy, self-concept and school achivment. In r. Riding \& s. Rayner (Eds.). London: Ablex Publishing.

Pintrich, P. R. 2003. A motivational science perspective on the role of student motivation in learning and teaching context. Journal of Education Psychology, 95, 667-686.

Poppen, R. 1982. The fixed-interval scallop in human affairs. The Behavior Analyst, 5, 127-136.

Ramsden, M. J. 1998. Mission imposibile?: Can anything be done about attitudes to science? International Journal of Science Education, 20, 2, 125-137.

Reiss, M. J. 2000. Understanding Science Lessons. Five years of science teaching. Buckingham: Open University Press. Rheinberg, F. 2004. Motivacija. Zagreb: Naklada Slap.

Rodek, S. 2010. Novi mediji i nova kultura učenja. Napredak, 151, 1, 9-28.

Rowlands, I. 2008. The Google generation: the information behaviour of the researcher in the future. Aslib Proceedings, 60 , 4, 290-310.

Sanfeliz, M., Stalzer, M. 2003. Science motivation in the multicultural classroom. The Science Teacher, 70, 39, 64-66.

Semb, G., Hopkins, B. L., \& Hursh, D. E. 1973. The effects of study questions and grades on student test performance in a college course. Journal of Applied Behavior Analysis, 6, 631-642.

Simon, S. 2000. Students attitudes towards science. In M. Monk \& J. Osborne (Eds.), Good practice in science teaching: What research has to say. Buckingham: Open University Press, 104-119.

Vidović, V. V., Rijavec, M., Štetić-Vlahović, V., Miljković, D. 2003. Psihologija obrazovanja. Zagreb: IEP-VERN.

Wood, W.B. 2009. Revising the AP biology curriculum. Science 325:1627-1628.

Zavod za školstvo Ministarstva kulture i prosvjete republike Hrvatske. (1993). Okvirni nastavni plan i program za osnovne škole u Republici Hrvatskoj u 1993/94. školskoj godini. Zagreb. 
Prilog 1 Anketni upitnik o očekivanju e-učenja iz biologije (samo za učenike eksperimentalne skupine, prije početka istraživanja)

\section{Datum___ _ D}

Razred:__Spol: M-Ž_ Zadnja zaključena ocjena iz biologije: 122345

Slijedećih nekoliko lekcija iz biologije učit ćeš on-line na računalu (e-učenje). Kako bismo mi učitelji bolje razumjeli što kao učenik očekuješ od takvog načina učenja molimo odgovori na slijedeća pitanja. Između ponuđenih odgovora odaberi jedan i obilježi ga znakom x.

\begin{tabular}{|c|c|c|c|c|c|}
\hline \multirow[b]{2}{*}{ Pitanja/skala } & 1 & 2 & 3 & 4 & 5 \\
\hline & $\begin{array}{l}\text { vrlo } \\
\text { malo }\end{array}$ & malo & umjereno & mnogo & $\begin{array}{l}\text { vrlo } \\
\text { mnogo }\end{array}$ \\
\hline \multicolumn{6}{|l|}{ 1.Zadovoljan/zadovoljna sam što ću koristiti e-učenja iz biologije } \\
\hline \multicolumn{6}{|l|}{ 2.Očekujem da će mi e-učenje pomoći u savladavanju odabranog gradiva iz biologije. } \\
\hline \multicolumn{6}{|l|}{ 3. Napor koji ću morati uložiti u e-učenje iz biologije bit će ... } \\
\hline \multicolumn{6}{|l|}{ 4. Zadaci za provjeru znanja on-line će biti razumljivi. } \\
\hline \multicolumn{6}{|l|}{$\begin{array}{l}\text { 5.Zadovoljan/zadovoljna sam što ću odmah imati uvid u ostvareni broj bodova iz e- } \\
\text { lekcije. }\end{array}$} \\
\hline \multicolumn{6}{|l|}{ 6.Tekst e- lekcija bit će jasan, razumljiv i zanimljiv. } \\
\hline \multicolumn{6}{|l|}{ 7.Glavni izbornik bit će jednostavan za snalaženje. } \\
\hline \multicolumn{6}{|l|}{ 8. Slike će bile jasne i zanimljive. } \\
\hline \multicolumn{6}{|l|}{ 9. e-lekcije imat će filmove. } \\
\hline \multicolumn{6}{|l|}{ 10. Dobit ću upute o e-učenju. } \\
\hline \multicolumn{6}{|l|}{ 11. Upute o načinu korištenja e-lekcija bit će jasne. } \\
\hline \multicolumn{6}{|l|}{ 12. Očekujem da je zanimljivije e-učenje biologije nego učenje biologije iz udžbenika. } \\
\hline Zamišljam e-lekcijama iz biologije kao: & & & & & \\
\hline
\end{tabular}

Prilog 2 Anketni upitnik o e-učenju iz biologije (samo za učenike eksperimentalne skupine, nakon provedenog istraživanja)

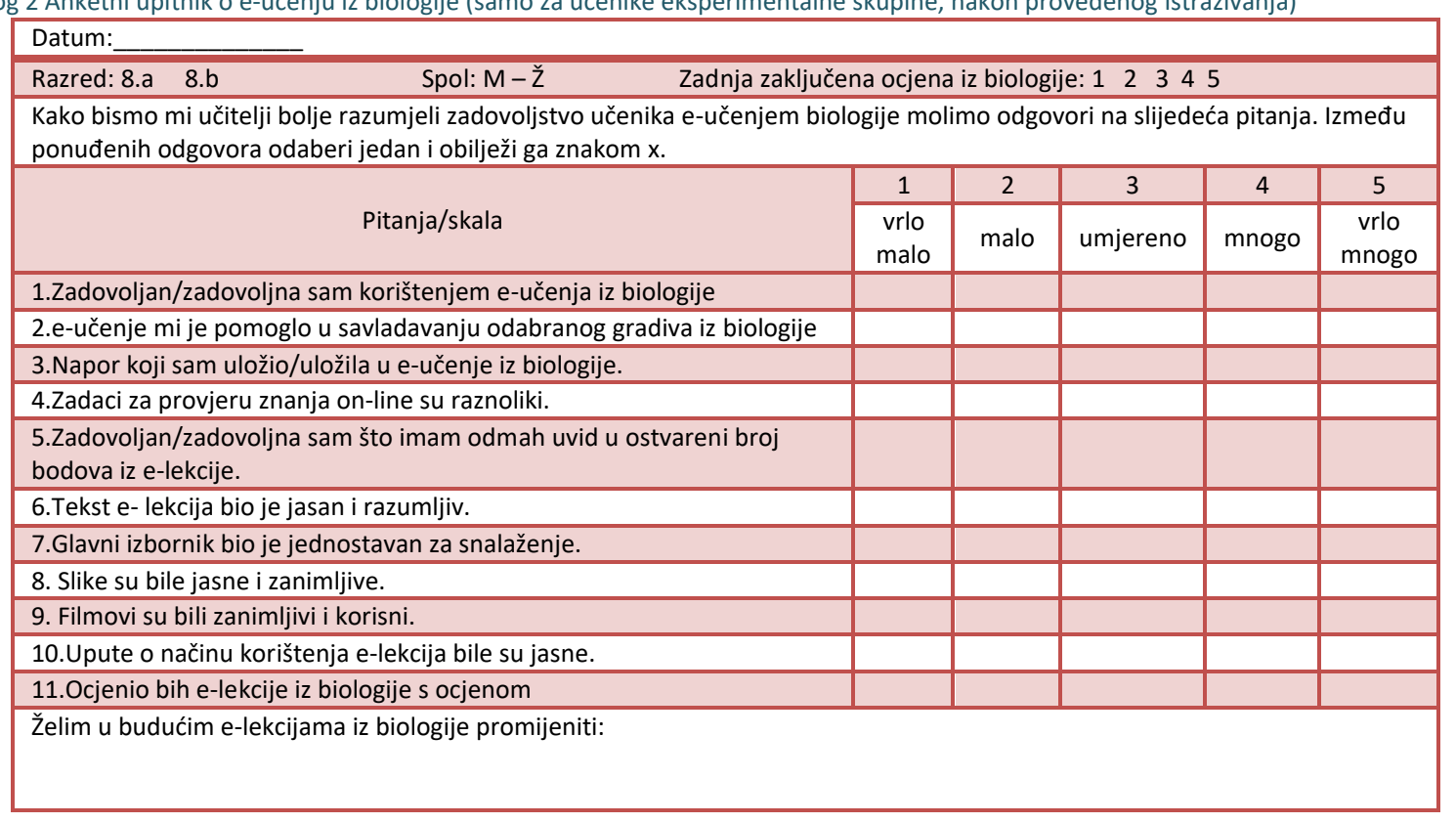

Novoselić, D., Bulić, M. 2017. Utjecaj učestalosti pristupanja e-nastavnim sadržajima biologije na usvojenost obrazovnih ishoda. Educ. biol. 3, 1, 127-142. 


\title{
EFFECT OF THE FREQUENCY OF ACCESS TO E-CONTENT OF BIOLOGY ON THE EDUCATIONAL OUTCOMES
}

\author{
Daniela Novoselić ${ }^{1}$, Mila Bulić ${ }^{2}$ \\ ${ }^{1}$ ALFA d.d., Zagreb, Croatia \\ daniela.novoselic@alfa.hr \\ ${ }^{2}$ University of Split, Faculty of Philosophy, Split, Croatia
}

\begin{abstract}
The aim of this research was to investigate the frequency of access of teaching contents of biology and the students' educational outcomes using the Moodle system, through its integration in eight grade biology lessons in "The human body, reproduction and development". The study was conducted among $14^{\text {th }}$ year old students who have not had any experience in e- learning in two eighth grades in one elementary school. The following hypothesis was set: if throughout the period of a five-week study of biology students frequently access the teaching contents of biology in the Moodle system, their educational outcomes will be greater. The study was conducted using questionnaires with questions to which answers were possible within 5-point Likert scales. The first questionnaire was given before the learning process and aimed to obtain information about what the students know and how they feel about e-learning, as well as what their expectations were of this learning method. The second questionnaire was given at the end of the e-learning process in order to record the students' experiences on the efficiency of using Moodle as a learning tool as well as their overall satisfaction of learning instructional content using the Moodle system. E-learning had fulfilled the students' expectations regarding the clarity and appeal of the lessons themselves as well as any pertaining issues, such as clarity of the main menu and the integration of images and movies. The analysis of the frequency of access to teaching content showed that students who have accessed the educational content more often achieved better results in the final written exam. The students did not actively access the teaching contents of biology using the Moodle system in periods when there was no teaching in the IT classroom.
\end{abstract}

Keywords: e -learning, Moodle, students' expectations, educational outcomes, eight grade biology lessons in "The human body, reproduction and development" 